\title{
The European Journal of Orthopaedic Surgery and Traumatology (EJOST) welcomes the Romanian Society of Orthopaedic Surgery (SOROT) as an official member
}

\author{
Marius M. Scarlat • Paul Botez · Pierre Kehr • \\ Cyril Mauffrey $\cdot$ Patrick Simon $\cdot$ Vincent Travers
}

Received: 21 November 2010 / Accepted: 26 November 2010 / Published online: 30 December 2010

(C) Springer-Verlag 2010

Each year in November the city of Paris hosts the Annual Meting of the French Academy of Orthopaedic Surgery. Each year, during this intense week, our publisher, Springer Verlag, organize the Board Meeting of the EJOST. It became a tradition for the members of the board to spend time together discussing projects of development and improvement for our publication, analyse statistics and trends, approve activities. This year the meeting was particularly intense. Honoured by the presence of the new associate Editor in Chief, Professor Paul Botez from Iasi, the Board meeting approved and welcomed the adhesion of the Romanian Society of Orthopaedic Surgery and Traumatology (SOROT) as an official member of the Journal (Fig. 1). The adhesion work started in 2008 when M. Scarlat participated in the National Congress of the SOROT in Oradea and made a presentation of the Journal. He used this occasion to invite the young orthopaedists to write and to publish in the EJOST. Several papers were submitted for publication in the EJOST after the meeting. In 2009 the SOROT Annual Congress discussed within the Board an official invitation to join the Journal. Our Editor, Pierre Kehr participated in this meeting and presented two Instructional Course Lectures. The Romanian Orthopaedic Society have an Orthopaedic Journal that is published in Romanian. The Director of the Romanian Journal, Pr. Gorun is a fine scientist who is a member of the Romanian Academy of Medicine. During the discussions it was

M. M. Scarlat $(\square) \cdot$ P. Botez $\cdot$ P. Kehr $\cdot$ C. Mauffrey $\cdot$ P. Simon . V. Travers

Clinique Chirurgicale St. Michel, Toulon, France

e-mail: mscarlat@gmail.com accepted the principle that the SOROT may adopt the EJOST as an official Journal and that the EJOST may consider for international publication the best papers proposed by the Romanian Journal of Orthopadics. The persons involved in the development of this new way of cooperation are Pr. Dan Poenaru from Timisoara, the President of the SOROT, Pr. Dumitru Stanculescu from Bucharest, the past president, Pr. Adrian Barbilian from Bucharest, Dr Calin Carstoiu, General Secretary of the SOROT and Pr. Paul Botez from Iasi who is the person in charge with the development of the Romanian participation to EJOST and who was appointed by the board of editors as a new Assistant Editor in Chief. His deputy is Pr. Tibi Bataga from Tg. Mures. As a result of this work the adhesion agreement was signed recently at the Springer headquarters in Paris. The relation between the EJOST and the SOROT started on excellent basis since more than 2 years and a major part of the members of the SOROT receive the printed version of the EJOST regularly.

The history of Romanian orthopaedics includes prestigious names as I. Juvara who described an original technique of knee fusion in tumour surgery in 1911 or I. Jianu who was a founding member of the SICOT. The first Romanian Society of Orthopaedics and Traumatology was founded in the city of CLUJ in 1935 at the initiative of Pr. Alexandru Radulescu. The society was rebuilt on modern principles on March 31 1990, the first president of the newly created society being Pr. Ion Dinulescu, a very fine surgeon and teacher who passed away a few years ago.

SOROT develops orthopaedics and Traumatology in Romania supporting and encouraging education, research, training specialists and specialty care, facilitating the exchange of professional experience in the country and abroad and promoting friendship and scientific debate among its members. 


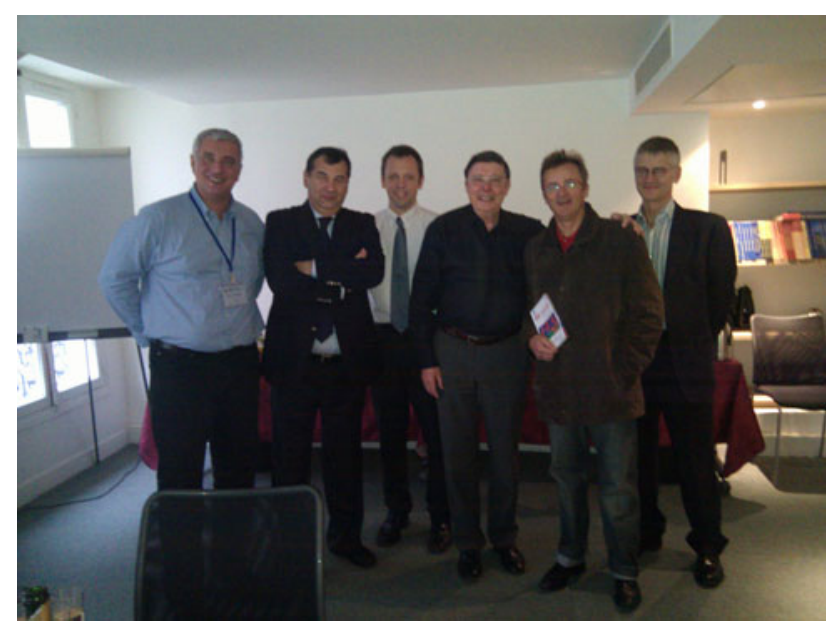

Fig. 1 The EJOST Editorial Board during the last meeting in Paris, November, 11, 2010; From Left to Right: Marius Scarlat, Paul Botez, Claus Roll, Pierre Kehr, Vincent Travers and Patrick Simon

The SOROT postal address is Ionel Perlea stret, Nr. 10, RO—010208 Bucharest, Tel: +40 $213141071,+402131410$ 62. The very active website is www.sorot.ro.

SOROT organizes every 2 years a National Congress of Orthopaedics and Traumatology with international participation and between the years of the Congress-a national conference. Lately, the national congress included EFORT sessions. In 2002 the SOROT organized in Bucharest The Eighth Congress of the AOLF (Association des Orthopedistes de Langue Francaise). The current president of the AOLF is Pr. Stefan Cristea, from Bucharest.

The SOROT president is elected for a term of 2 years, by vote of the General Assembly. A series of orthopaedic personalities have filled this prestigious function: Pr. Gh. Niculescu, Pr. A. Denischi, Pr. O. Medrea, Pr. D. Antonescu, Pr. N. Georgescu, Pr. N. Gorun, Pr. A. Pop, P. A. Firica, Pr. N. Ors, Pr. D. Stanculescu, etc.
A special word for the major orthopaedic writer in Romania who was Dr. Clement Baciu, an extremely charismatic and efficacious surgeon, dedicated sportsman and academic teacher. He did not occupied the official function of Professor because of his political views and tumultuous life that was not well seen in Communist Romania. Clement Baciu wrote a series of books who are perfectly valid in our days, mainly a textbook of pathology (Aparatul Locomotor) and the first textbook of Orthopaedic Techniques, in the late ' $80 \mathrm{~s}$. His international publications include an original technique of ankle fusion and several case-series with long-term follow-up.

The Romanian Society of Orthopaedics and Traumatology is affiliated to a number of international companies: EFFORT-European Federation of National Associations of ORTHOPEDICS and Traumatology, SICOT—Societe Internationale et Orthopedique Trauma Surgery, AOLFAssociation des Orthopedistes the Langue Francaise.

Currently the SOROT created the National Arthroplasty Register funded by the National Public Health Program entitled "Prevention in orthopedics and Traumatology". Today more than 35,000 registered personal records are included for patients with prosthetic replacement of hip (primary and revision).

The current projects of the EJOST in Romania are related to young surgeons education, teaching them the best possible tools in order scientific writing. The upcoming Congress of Orthopaedics in Timisoara will be held between 18 and 20 October 2011. The congress will include a medical writing session organized by the EJOST. Other topics of the congress are "The Cervical Spine" "The Knee, from Arthroscopy to Arthroplasty" and "Pelvic Trauma".

So, let there be fun for our new member of the family and let's celebrate together new openings and prospectives for European Orthopaedics.

Acknowledgments No funds were received in support of this study. 